\title{
Selection and Preparation of Planting Material for Successful Hop Production in Florida ${ }^{1}$
}

\author{
Shinsuke Agehara, Aleyda Acosta-Rangel, Mariel Gallardo, and Gary Vallad ${ }^{2}$
}

Hops (Humulus lupulus L.), an essential ingredient in beer, have the potential to develop as a viable alternative crop in Florida. In 2019, Florida ranked fourth in the nation for craft beer production, with 329 breweries producing 42.6 million gallons of beer and generating an economic impact of more than $\$ 3$ billion (Brewers Association 2019). In our surveys, many breweries have expressed strong interest in using locally grown hops. However, hop production is not without risk. Globally, hop production is plagued by many diseases, most of which were inadvertently introduced through the movement of contaminated planting material. The primary purposes of this article are to prevent the introduction of these diseases into the state and to provide recommendations for selecting and preparing planting material for successful hop production in Florida. This article is part of a larger series that will review the challenges of hop production, based on research experience at the UF/IFAS Gulf Coast Research and Education Center (UF/IFAS GCREC) in Balm, FL.

\section{Propagation Methods}

Hops are dioecious, meaning they have separate male and female plants. Only female hop plants produce strobiles, or cones, that are used in beer brewing. Because plants will vary in gender when propagated from seeds, only vegetative (asexual) propagation via rhizomes, cuttings, or tissue culture is used for commercial hop production. Although propagation via rhizomes and cuttings is relatively easy and inexpensive, it has a high contamination risk. In fact, many fungal, viral, and viroid (small infectious RNA with no protein coating) pathogens have been spread worldwide via contaminated planting material. Among these diseases, the two most common and economically important fungal diseases are downy mildew, caused by the fungus-like organism Pseudoperonospora humuli (Gent et al. 2015a), and powdery mildew, caused by the fungus Podosphaera macularis (Gent et al. 2015b). The most widespread and destructive hop viruses include Apple mosaic virus (ApMV), Hop mosaic virus (HpMV), and Hop latent virus (HpLV) (Eastwell and Barbara 2015a; Eastwell and Barbara 2015b). Significant yield loss caused by two viroids, Hop latent viroid and Hop stunt viroid, has also been reported in the United States (Eastwell 2015; Eastwell and Barbara 2015c). Despite the global efforts to develop a clean plant program based on tissue-cultured plants, many of these pathogens are now endemic to most hop production areas outside of Florida.

To date, Florida does not have production issues with pathogens typically associated with hop production throughout the world. To avoid the possibility of introducing these pathogens into the state, Florida growers are strongly encouraged to use tissue-cultured seedlings that are certified virus-free. We do not recommend using rhizomes and cuttings because of the high likelihood of

1. This document is HS1381, one of a series of the Horticultural Sciences Department, UF/IFAS Extension. Original publication date September 2020. Visit the EDIS website at https://edis.ifas.ufl.edu for the currently supported version of this publication.

2. Shinsuke Agehara, assistant professor, Horticultural Sciences Department; Aleyda Acosta-Rangel, postdoctoral associate; Mariel Gallardo, graduate research assistant; and Gary Vallad, associate professor, Plant Pathology Department, UF/IFAS Gulf Coast Research and Education Center, Balm, FL 33598.

The Institute of Food and Agricultural Sciences (IFAS) is an Equal Opportunity Institution authorized to provide research, educational information and other services

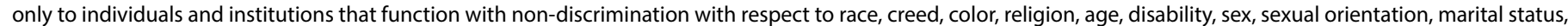

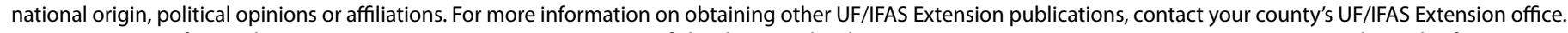
U.S. Department of Agriculture, UF/IFAS Extension Service, University of Florida, IFAS, Florida A \& M University Cooperative Extension Program, and Boards of County Commissioners Cooperating. Nick T. Place, dean for UF/IFAS Extension. 
being infected. Once infected plants are introduced into a hop yard, pathogens will spread to other plants through the production of spores (downy mildew and powdery mildew) or mechanical transmission (viruses and viroids). Although effective fungicides for downy mildew and powdery mildew are available, given Florida's weather conditions, chemical management for these diseases might not be economically feasible. For viruses and viroids, there are no effective pesticide options, so preventing their entry and eradicating infected plants are the only management options available to Florida growers.

\section{Tissue Culture}

Plant tissue culture is a collection of techniques involving the use of small pieces of plant tissue cultured in a nutrient medium under sterile conditions (George et al. 2008).

Tissue culture can be used as both disease elimination and propagation methods. Microshoot tip culture, often combined with heat therapy or chemotherapy, can eliminate viral and other infections from plants and produce clean planting stock. In the horticulture industry, tissue culture is often used for commercial production of virus-free plants.

The Clean Plant Center Northwest (http://cpcnw.wsu.edu/) is a member of the National Clean Plant Network for Hops (http://nationalcleanplantnetwork.org/HOPS_CPN/) and is based at the Washington State University Irrigated Agriculture Research and Extension Center in Prosser, Washington. The Clean Plant Center Northwest uses tissue culture techniques to provide clean planting stock that is free of known hop viruses and viroids. To ensure that you are starting off with clean planting material, you may purchase planting stock from the National Clean Plant Network and propagate it yourself. Some commercial nurseries located in Florida may be able to assist in propagation. Tissuecultured seedlings can also be purchased from commercial nurseries (see the "Timing and Planting Material" section for more details).

\section{Rhizomes}

A rhizome is a modified underground stem that can develop new shoots and roots from its nodes. Although rhizomes are used as a common propagation material in major hop-producing states, we do not recommend using rhizomes because they have a high likelihood of being infected with fungal or viral pathogens. In fact, some rhizomes purchased from commercial nurseries and planted at the UF/IFAS GCREC were diagnosed to be infected with Apple mosaic virus, Hop mosaic virus, and Hop latent virus shortly after planting. At the end of the season, we removed all the plants and fumigated the entire field.
Since the reestablishment of the GCREC hop yard in 2017 with tissue-cultured seedlings, we have not experienced any serious disease issues.

\section{Seeds}

Seeds should not be used for propagation of hops because plants grown from seeds will vary in gender. Male plants are not desirable for commercial hop growers not only because they do not produce cones, but also because female plants could become pollinated and produce seeds in cones. A high level of fatty acids in seeds can negatively affect the flavor profile and stability of beer (Neve 1991). In major hop-producing areas, tremendous efforts have been made to remove male plants near commercial hop yards. Male plants are, however, essential in hop breeding programs to develop new hop cultivars.

\section{Preparing Seedlings from Tissue- Cultured Liners for Field Planting Timing and Planting Material}

We recommend planting hops in early spring after the danger of frost has passed. In central Florida, for example, the optimal planting time is mid-February through early March.

Although tissue-cultured hop seedlings can be purchased from commercial nurseries in major hop-producing states such as Washington, Oregon, Michigan, and New York, seedlings are normally available only after early April, the beginning of their planting season. To plant at the optimal time in Florida, therefore, you may use seedlings propagated locally. Obtaining tissue-cultured plants produced in Florida can also decrease the likelihood of introducing fungal pathogens that cause downy mildew or powdery mildew, because neither pathogen is reported in the state.

Currently, only one nursery (Agri-Starts, Apopka, FL) supplies tissue-cultured hop seedlings in Florida. Check the availability and size of seedlings in advance. Small liners may need to be transplanted and grown in pots until they reach a suitable size for planting in the field. This process may take 4 to 6 weeks, depending on the size of liners and growing conditions. Figure 1 shows 'Cascade' hop liners delivered from this nursery, and Figure 2 shows a mature seedling ready for field setting. For a field trial established at the GCREC in 2020, we transplanted liners into pots in mid-January and grew them at our greenhouse for about 5 weeks before planting them in the field. 


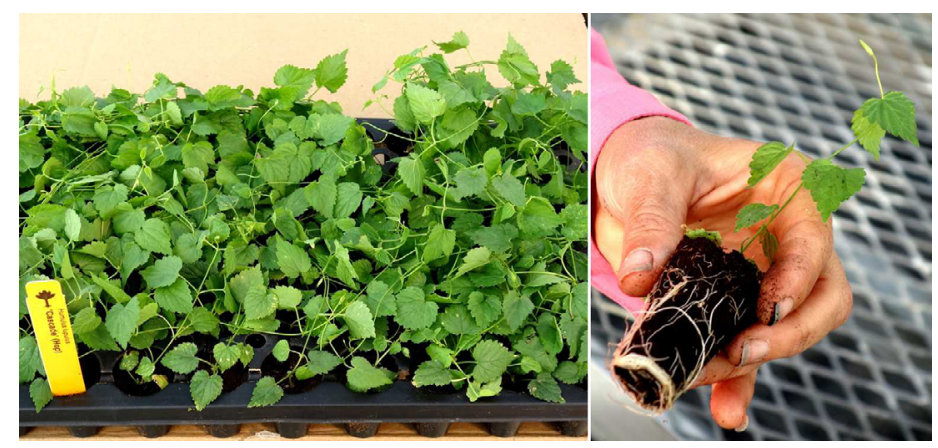

Figure 1. 'Cascade' hop tissue-cultured liners. These liners need to be transplanted and grown in pots until they reach a suitable size for field setting.

Credits: Shinsuke Agehara, UF/IFAS

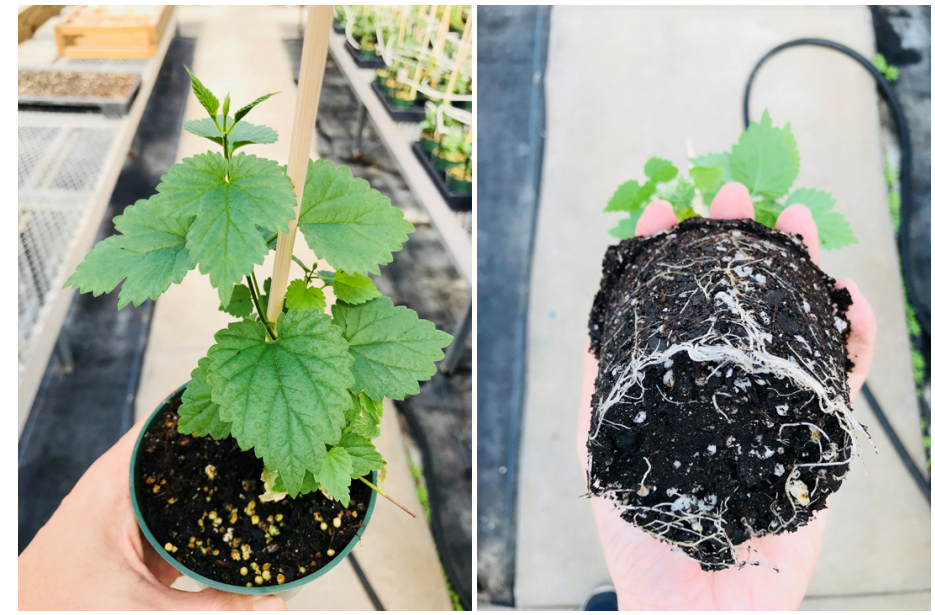

Figure 2. A 'Cascade' hop tissue-cultured seedling ready for field setting.

Credits: Shinsuke Agehara, UF/IFAS

\section{Pots}

Choosing the right pot size is critical not only for growing healthy plants but also for saving costs. In pots that are too small, potting mixes dry so quickly that it will become challenging to maintain moisture and salinity at the optimum level. Plants may also become root-bound quickly, which can negatively affect root development and establishment in the field. If pots are too large, by contrast, potting mixes dry too slowly, making plants more vulnerable to root rot diseases caused by opportunistic Pythium and Fusarium species. Larger pots also require more material costs (e.g., pots, growth media, water, fertilizers), greenhouse space, and labor per plant.

The ideal pot size can be determined based on the initial size of liners and the target size of mature seedlings. For liners shown in Figure 1, the pot size we recommend is 4 inches in diameter. Carrying trays can prevent pots from tipping over and facilitate efficient spacing and transportation of pots. Pesticide application and training of bines (twining stems) can be performed more efficiently when pots are evenly spaced and secured in trays.

\section{Potting Mix}

Potting mixes used in the greenhouse industry contain a variety of soilless materials, such as peat moss, vermiculite, perlite, coconut coir, and composted bark. These materials are ideal for growing plants in containers because they are lightweight and provide high water-holding capacity, aeration, and drainage.

There are many commercial potting mix products, which are blended differently for specific propagation and crops, or for general purposes. For growing hop seedlings in 4 -inch pots, we recommend general-purpose potting mixes that are low density with superior drainage and aeration. The potting mix we used is composed of sphagnum peat moss, aged pine bark fines, perlite, and vermiculite, and it has a density of 14 to 16 pounds per cubic foot. We added additional perlite to this potting mix at a ratio of 1:9 to improve aeration and drainage. It is crucial not to compress a potting mix when filling pots. Otherwise, aeration and drainage properties of the potting mix will be compromised, which can lead to issues with root rot diseases.

\section{Irrigation}

Irrigation frequency and rate should be determined based on your pot size, water-holding capacity of your potting mix, plant water use, optimum moisture and aeration for your crop, and environmental conditions. The general rule of thumb for greenhouse irrigation is to maintain medium moisture above $50 \%$ of water-holding capacity (Merhaut 2014). It is important to allow growth media to dry out between irrigation cycles to maintain proper drainage and prevent root diseases. In the meantime, care must be taken not to overdry growth media. Otherwise, uniform rewetting of peat moss will be very difficult. Overwatering that leads to poor aeration and nutrient leaching should also be avoided. For more technical information about greenhouse irrigation, see https://edis.ifas.ufl.edu/cv264 (Hochmuth 2015).

Figure 3 shows the irrigation system used to grow hop seedlings in our greenhouse. Eight angle drippers were connected to a 2-gallons-per-hour, pressure-compensating emitter using two 4 -way emitter splitters. One dripper was used per pot, providing $16 \mathrm{~mL}(0.54 \mathrm{fl} \mathrm{oz})$ of water per minute. Our initial irrigation program was one cycle of three minutes every other day, but it was increased to one cycle of five minutes per day before seedlings reached the optimum size for field setting. 


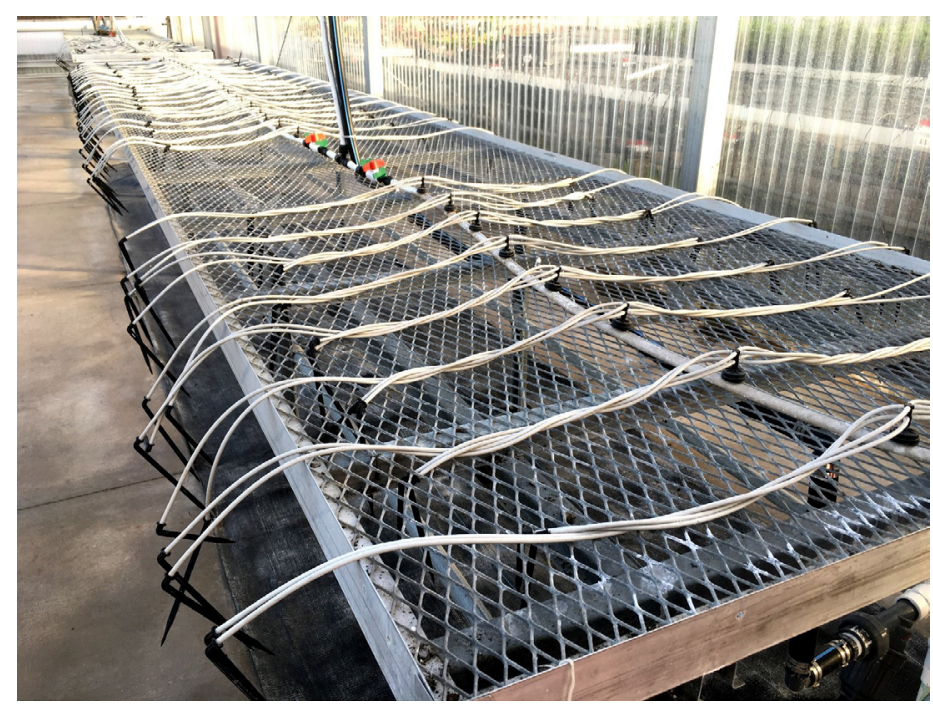

Figure 3. The drip irrigation system used to grow hop seedlings at the UF/IFAS GCREC in Balm, FL. Eight angle drippers were connected to a 2-gallons-per-hour, pressure-compensating emitter using two 4-way emitter splitters.

Credits: Shinsuke Agehara, UF/IFAS

\section{Fertilization}

Most potting mixes contain insufficient amounts of nutrients and will not sustain plant growth without additional fertilizer application. In greenhouse production of container-grown plants, nutrients are generally delivered using water-soluble fertilizers with irrigation water (fertigation) or through granular application of controlled-release fertilizers. Fertigation provides flexibility to change fertilizer formulations and application rates, whereas the primary benefits of using controlled-release fertilizers are ease of use and potential reduction of nutrient leaching. Both fertilization methods can be used for growing hop seedlings in a greenhouse. Criteria for choosing one over the other include the number of plants to grow, labor, and available equipment.

Fertilizers are available in many different formulations. It is important to choose a formulation that closely matches the plant nutrient requirement. Optimum nutrient concentration ranges in hop petioles are $3.2 \%-5.6 \%, 0.27 \%-0.54 \%$, and $1.6 \%-3.4 \%$, for nitrogen, phosphorus, and potassium, respectively (Sirrine 2019). The tissue analysis of our leaf samples also showed similar nutrient concentration ranges. Therefore, we recommend a formulation that is relatively high in nitrogen and low in phosphorus. It is also important to choose a fertilizer that contains micronutrients. In our greenhouse, iron is the most common micronutrient deficiency observed (Figure 4).

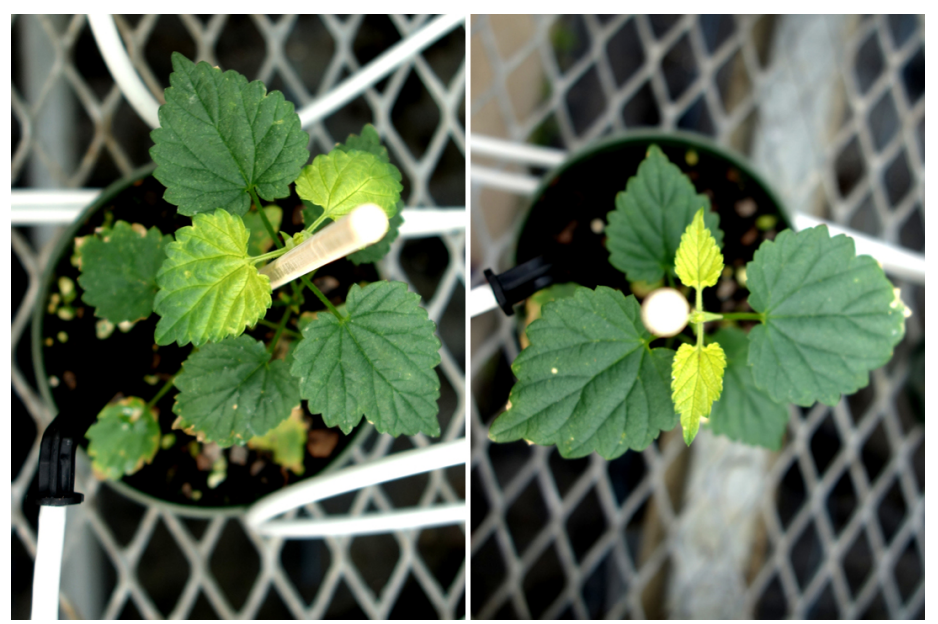

Figure 4. 'Cascade' hop seedlings with iron deficiency symptoms. Symptoms appear on newly emerging leaves. The most common symptom is interveinal chlorosis, with leaf lamina turning yellow and veins remaining green. In severe cases, new leaves will remain small and turn almost white, and growing tips may start to die back. Credits: Shinsuke Agehara, UF/IFAS GCREC

In our fertilization program, we used a controlled-release fertilizer (Osmocote Plus, 15-9-12, 3-4 month release) in top-dress application. The standard nutrient release duration of this fertilizer is 3-4 months, although it varies depending on temperature and moisture (e.g., 3-4 months at $70^{\circ} \mathrm{F}$ and $2-3$ months at $80^{\circ} \mathrm{F}$ ). It contains nitrogen (15\%), phosphate (9\%), potash (12\%), magnesium (1.3\%), sulfur (5.9\%), and six micronutrients. Immediately after transplanting, a teaspoon of this fertilizer (about 2 grams) was sprinkled onto the surface of the potting mix in each pot, avoiding direct contact with the stems. We also used a micronutrient fertilizer (Microplex) to supply additional micronutrients via fertigation. This fertilizer is watersoluble and contains high concentrations of copper (1.5\%), iron (4\%), manganese (4\%), and zinc (1.5\%). The nutrient solution containing 2.5 grams of the fertilizer per liter ( $0.33 \mathrm{oz}$ per gallon) was applied at $50 \mathrm{~mL}(1.7 \mathrm{fl} \mathrm{oz})$ per pot weekly starting one week after transplanting.

\section{Bine Training}

Hop plants tend to grow vertically by developing twining stems called bines. A support system is necessary, not only to promote vertical bine growth but also to prevent plants from tangling with each other in a greenhouse. We used a bamboo skewer (17.3 inches long and 0.2 inches thick) as a stake in each pot (Figures 2 and 4). This bamboo skewer is ideal for training hop bines in a small pot because it is light enough to be held by the pot and its rough surface is easy for bines to climb up. Hop bines climb in a clockwise direction, so it is important to train bines following this natural tendency. Bines need to be trained once a week initially, then twice a week once they start growing rapidly. 


\section{Disease Control}

Root rots commonly associated with opportunistic Pythium and Fusarium species can be a problem in greenhouses. However, in our experience, most of these issues are associated with plants being overwatered, overfertilized (leading to high salts), and root-bound. The cultural practices discussed in earlier sections (proper fertilization, irrigation, potting mix, and pot selection) can help avoid complications from these diseases. The use of preventative fungicides (Table 1) may help treat affected plant materials, but users should always try to address any underlying cultural causes first.

\section{Pest Control}

Common pests of hops observed in greenhouses at the UF/IFAS GCREC include spider mites, thrips, and aphids. Among these pests, spider mites, including two-spotted spider mite (Tetranychus urticae) and red spider mite (Tetranychus urticae), routinely establish on hop seedlings and can cause significant damage if not managed. Although chemical options are available for mite control (e.g., Abamectin, Acequinocyl, Etoxazole, Fenazaquin, Hexythiazox), the best results managing spider mites have been obtained through applications of a commercially available predatory mite, Phytoseiulus persimilis.

\section{Sanitation}

Sanitation is another important cultural practice for any greenhouse-produced plant. Ensuring all pots are clean of plant debris from previous uses is extremely important, especially because many viral and viroid pathogens can be mechanically transmitted. Sanitation is also important to minimize any issues with common opportunistic pathogens, such as Botrytis, Alternaria, Fusarium, and Pythium. It is always ideal to wash greenhouse surfaces, equipment, and tools used to prune plants with an approved sanitizer such as household bleach (10\% solution), ethanol (70\% solution), quaternary ammonium (e.g., Green Shield, Physan 20), hydrogen dioxide (e.g., OxiDate, ZeroTol), and other multipurpose disinfectants like Virkon. Use caution when preparing and using these cleaning products: bleach is highly volatile and phytotoxic, and ethanol is flammable. For a comprehensive list of cleaning products, see https://www.freshfromflorida.com/content/ download/9901/135674/decontamination.pdf (Florida Department of Agriculture and Consumer Services 2017). These products are approved for the Citrus Health Response Program, but they should also be effective against many infective agents of hops.

\section{Planting}

A hop seedling at the ideal size for field setting should have a healthy and sturdy root system in the entire pot (Figure 2 ), so it can be easily pulled out of the pot without damaging roots. We recommend planting two seedlings per hill. If seedlings are root-bound in pots, untangle the roots with your fingers before planting. Make a planting hole wide and deep enough to insert the entire root system, and cover the surface of the potting mix with 0.25 to 0.5 inches of soil. Finally, apply pine bark fines around the plants to cover the soil to minimize evaporation and suppress weed growth. Figure 5 shows hop seedlings 14 days after transplanting at the GCREC hop yard. Plants should be watered immediately after planting. The controlled-release fertilizer applied in the greenhouse should continue to release nutrients for a while, but we recommend starting fertigation within a week after planting to encourage new root growth into the field soil. For field preparation, see https://edis.ifas.ufl.edu/ hs1354 (Agehara et al. 2020).

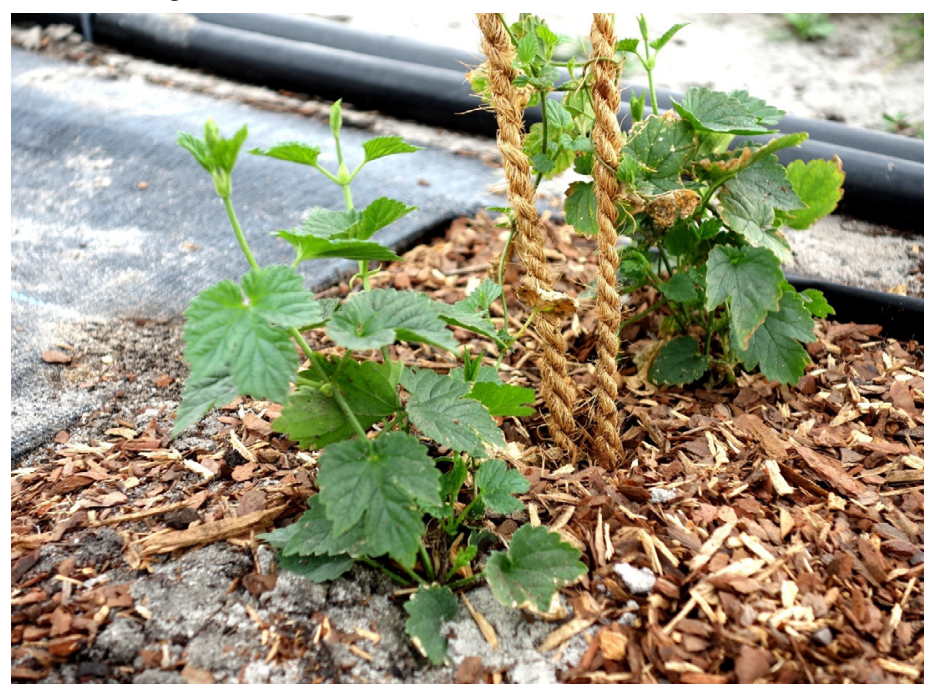

Figure 5. 'Cascade' hop seedlings 14 days after transplanting at the UF/ IFAS GCREC research hop yard in Balm, FL.

Credits: Shinsuke Agehara, UF/IFAS

\section{Plant Diagnostics}

Regardless of where hop plant materials are sourced, it is vital to have plants tested to ensure they are free of viral and viroid pathogens. Third party vendors like Agdia can provide an array of test services for hops (http://www.agdia. com/testing-services/hops). As mentioned earlier, obtaining tissue-cultured plants from the Clean Plant Center Northwest can assure planting material is free of viruses and viroids. Currently, Agri-Starts is the only Florida-based nursery that supplies tissue-cultured hop seedlings. 


\section{Literature Cited}

Agehara, S., A. Acosta-Rangel, Z. Deng, J. Rechcigl, and S. Bollin. 2020. Hop Yard Establishment and Trellis Construction in Florida. HS1354. Gainesville: University of Florida Institute of Food and Agricultural Sciences. https://edis.ifas. ufl.edu/hs1354

Brewers Association. 2019. "Florida's Craft Beer Sales and Production Statistics, 2018." Accessed Apr. 28, 2020. https://www.brewersassociation.org/statistics-and-data/ state-craft-beer-stats/?state $=\mathrm{FL}$

Eastwell, K. C. 2015. “Hop Stunt Viroid.” In Field Guide for Integrated Pest Management in Hops, 3rd Ed, edited by S. D. O’Neal, D. B. Walsh, and D. H. Gent. Yakima, WA: US Hop Industry Plant Protection Committee.

Eastwell, K. C. and D. J. Barbara. 2015a. "Apple Mosaic Virus." In Field Guide for Integrated Pest Management in Hops, 3rd Ed, edited by S. D. O'Neal, D. B. Walsh, and D. H. Gent. Yakima, WA: US Hop Industry Plant Protection Committee.

Eastwell, K.C. and D.J. Barbara. 2015b. "Carlavirus Complex: American Hop Latent Virus, Hop Latent Virus, and Hop Mosaic Virus." In Field Guide for Integrated Pest Management in Hops, 3rd Ed, edited by S. D. O'Neal, D. B. Walsh, and D. H. Gent. Yakima, WA: US Hop Industry Plant Protection Committee.

Eastwell, K. C. and D. J. Barbara. 2015c. "Other Viruses, Viroids, and Virus-like Agents." In Field Guide for Integrated Pest Management in Hops, 3rd Ed, edited by S. D. O'Neal, D. B. Walsh, and D. H. Gent. Yakima, WA: US Hop Industry Plant Protection Committee.

Florida Department of Agriculture and Consumer Services. 2017. "Approved Decontamination Products \& Methods." Accessed Apr. 28, 2020. https://www.fdacs.gov/content/ download/9901/file/decontamination.pdf

Gent, D. H., D. A. Johnson, A. J. Gevens, and M. K. Hausbeck. 2015a. "Downy Mildew." In Field Guide for Integrated Pest Management in Hops, 3rd Ed, edited by S. D. O'Neal, D. B. Walsh, and D. H. Gent. Yakima, WA: US Hop Industry Plant Protection Committee.

Gent, D. H., M. E. Nelson, D. M. Gadoury, A. J. Gevens, and M. K. Hausbeck. 2015b. "Powdery Mildew." In Field Guide for Integrated Pest Management in Hops, 3rd Ed, edited by S. D. O'Neal, D. B. Walsh, and D. H. Gent. Yakima, WA: US Hop Industry Plant Protection Committee.
George, E. F., M. A. Hall, and G. De Klerk. 2008. Plant Propagation by Tissue Culture. 3rd Ed. Dordrecht, The Netherlands: Springer.

Hochmuth, G. 2015. Irrigation of Greenhouse VegetablesFlorida Greenhouse Vegetable Production Handbook, Vol 3. HS786. Gainesville: University of Florida Institute of Food and Agricultural Sciences. https://edis.ifas.ufl.edu/cv264

Merhaut, D. 2014. "Get Cultured: Managing Media to Optimize Water Use.” UCNFA News. 18 (2): 13-15.

Neve, R. A. 1991. Hops. Berlin: Springer Science \& Business Media.

Sirrine, R. 2019. "Recommended Nutrient Ranges for Hop Petiole Samples." Accessed Apr. 28, 2020. https://www.usahops.org/growers/ recommended-nutrient-ranges-for-hop-peti 
Table 1. Preventative fungicides labelled for the management of common soilborne pathogens (Pythium, Phytophthora, Rhizoctonia, and Fusarium spp.) that cause root rot on hop liners, potted seedlings, and field plants.

\begin{tabular}{|c|c|c|c|c|}
\hline $\begin{array}{l}\text { Fungicide } \\
\text { (active ingredients) }\end{array}$ & $\begin{array}{l}\text { FRAC } \\
\text { Code }^{1}\end{array}$ & $\begin{array}{l}\text { Reentry } \\
\text { interval }\end{array}$ & $\begin{array}{l}\text { OMRI } \\
\text { listed }\end{array}$ & Remarks $^{2}$ \\
\hline $\begin{array}{l}\text { Brandt Organics Aleo } \\
\text { (garlic oil) }\end{array}$ & NC & $0 \mathrm{hr}$ & YES & $\begin{array}{l}\text { Can be applied to foliage; do not apply when plants are stressed or air } \\
\text { temperature is }>90^{\circ} \mathrm{F} \text {. If applying to liners or small potted plants, use } \\
\text { rates described for ornamental crops. See label. }\end{array}$ \\
\hline $\begin{array}{l}\text { Confine } \\
\text { (phosphorous acid, mono- } \\
\text { and dipotassium salts) }\end{array}$ & 33 & $4 \mathrm{hr}$ & NO & Can be applied to foliage, as a drench, or through irrigation. See label. \\
\hline $\begin{array}{l}\text { Custos } \\
\text { (garlic oil, excipient, } \\
\text { rosemary oil, peppermint) }\end{array}$ & NC & 0 & YES & $\begin{array}{l}\text { Can be applied to foliage; do not apply when plants are stressed or air } \\
\text { temperature is }>90^{\circ} \mathrm{F} \text {. See label. }\end{array}$ \\
\hline $\begin{array}{l}\text { K-Phite 7LP } \\
\text { (phosphorous acid, mono- } \\
\text { and dipotassium salts) }\end{array}$ & 33 & $4 \mathrm{hr}$ & NO & Can be applied to foliage, as a drench, or through irrigation. See label. \\
\hline $\begin{array}{l}\text { Pvent } \\
\text { (Gliocladium catenulatum } \\
\text { Strain J1446) }\end{array}$ & NC & $4 \mathrm{hr}$ & YES & $\begin{array}{l}\text { Can be applied to foliage, as a drench, through irrigation, or by } \\
\text { incorporating into potting media. See label. }\end{array}$ \\
\hline $\begin{array}{l}\text { Rampart } \\
\text { (phosphorous acid, mono- } \\
\text { and dipotassium salts) }\end{array}$ & 33 & $4 \mathrm{hr}$ & NO & Can be applied to foliage or through irrigation. See label. \\
\hline $\begin{array}{l}\text { Resist } 57 \\
\text { (phosphorous acid, mono- } \\
\text { and dipotassium salts) }\end{array}$ & 33 & $4 \mathrm{hr}$ & NO & Can be applied to foliage or through irrigation. See label. \\
\hline $\begin{array}{l}\text { SaniDate } 12.0 \\
\text { (hydrogen peroxide, } \\
\text { peroxyacetic acid) }\end{array}$ & NC & $0 \mathrm{hr}$ & NO & $\begin{array}{l}\text { Can be applied to foliage, as a drench, through irrigation, or as a } \\
\text { preplant dip. See label for specific application instructions. }\end{array}$ \\
\hline $\begin{array}{l}\text { Serenade ASO } \\
\text { (Bacillus subtilis strain QST } \\
\text { 713) }\end{array}$ & 44 & $4 \mathrm{hr}$ & YES & Can be applied to soil to target soilborne pathogens. See label. \\
\hline $\begin{array}{l}\text { SporeQuell } 15 \% \\
\text { (hydrogen peroxide, } \\
\text { peroxyacetic acid) }\end{array}$ & NC & $0 \mathrm{hr}$ & NO & $\begin{array}{l}\text { Can be applied to foliage, as a drench, through irrigation, or as a } \\
\text { preplant dip. See label for specific application instructions. }\end{array}$ \\
\hline $\begin{array}{l}\text { TerraClean } 5.0 \\
\text { (hydrogen peroxide, } \\
\text { peroxyacetic acid) }\end{array}$ & NC & $0 \mathrm{hr}$ & NO & $\begin{array}{l}\text { Can be applied to foliage, as a drench, through irrigation, or as a } \\
\text { preplant dip. See label for specific application instructions. }\end{array}$ \\
\hline $\begin{array}{l}\text { Veg'lys } \\
\text { (garlic oil) }\end{array}$ & NC & $0 \mathrm{hr}$ & YES & $\begin{array}{l}\text { Can be applied to foliage; do not apply when plants are stressed or air } \\
\text { temperature is }>90^{\circ} \mathrm{F} \text {. If applying to liners or small potted plants, use } \\
\text { rates described for ornamental crops. See label. }\end{array}$ \\
\hline \multicolumn{5}{|c|}{$\begin{array}{l}1 \text { FRAC code (fungicide group): Number ( } 33 \text { and } 44 \text { ) and letters (NC) are used to distinguish the fungicide mode of action groups. All fungicides } \\
\text { within the same group (with same number or letter) indicate same active ingredient or similar mode of action. This information must be } \\
\text { considered for the fungicide resistance management decisions. However, products with NC are considered low risk and do not require any } \\
\text { rotation unless specifically directed on the label. NC = not classified, includes mineral oils, organic oils, potassium bicarbonate, and other } \\
\text { materials of biological origin. Source: FRAC Code List 2019; http://www.frac.info/ (FRAC = Fungicide Resistance Action Committee). } \\
{ }^{2} \text { Information provided in this table applies only to Florida. Be sure to read a current product label before applying any product. The use } \\
\text { of brand names and any mention or listing of commercial products or services in the publication does not imply endorsement by UF/IFAS } \\
\text { Extension nor discrimination against similar products or services not mentioned. }\end{array}$} \\
\hline
\end{tabular}

